\title{
КЛАСИФІКАЦІЯ ДОГОВОРІВ У ПРАВІ СОЦІАЛЬНОГО ЗАБЕЗПЕЧЕННЯ
}

Гудзь О. 0.

у науковій статті досліджено види договорів у праві соціального забезпечення. Розглядаються різні критерії для проведення їх класифікації. Доведено, що найбільш фундаментальним критерієм, на нашу думку, є поділ усієі сукупності договорів у праві соціального забезпечення на нормативно-правові договори та індивідуальні. Така диференціація одночасно з теоретичним навантаженням може відігравати важливу роль на практиці, адже впливатиме на найменш спірне і найбільш чітке висвітлення окремих аспектів договірного регулювання у чинному законодавстві України: порядку та сфери їх застосування, процедури укладання та їх подальшої динаміки тощо.

Ключові слова: договір, право соціального забезпе чення, договірне регулювання, індивідуальний договір, нормативний договір.

В научной статье исследованы виды договоров в праве социального обеспечения. Рассматриваются различные критерии для проведения их классификации. Доказано, что наиболее фундаментальным критерием, по нашему мнению, является разделение всей совокупности договоров в праве социального обеспечения на нормативно-правовые договоры и индивидуальные. Такая дифференциация одновременно с теоретической нагрузкой может играть важную роль на практике, ведь будет влиять на наименее спорное и наиболее четкое освещение отдельных аспектов договорного регулирования в действующем законодательстве Украины: порядка и сферы их применения, процедуры заключения и их дальнейшей динамики и тому подобное.

Ключевые слова: договор, право социального обеспечения, договорное регулирование, индивидуальный договор, нормативный договор.

There are a great number of social security contracts. In addition, different approaches to understanding of this legal category give grounds to further multiply their not so small volume. The diversity of the investigated phenomenon becomes possible to be understood by systematizing existing treaties. Ordering any objects, phenomena, processes, characteristics, etc. can be done by their classification, the most important task of which is - the formation of a unified, logical, accessible for understanding system. For the purpose of classification, the fundamental value is the selection of successful criteria for the delineation of elements of the entire set of contracts.

Different criteria for the classification of contracts are considered in the scientific article: subject composition; number of subjects; scope of application; the level of the act, which ensures the possibility of their conclusion, etc.

It is proved that the most fundamental criterion, in our opinion, is the division of the entire set of contracts in the law of social security into normative and legal agreements and individual. The main difference between these groups of contracts is that some of them are recognized as sources of social security law, while others are only used to streamline relations between individual entities. Moreover, such a division allows logically distinguishing independent types of contracts in each of these groups.

The proposed differentiation simultaneously with the theoretical value can play an important role in practice, since it will affect the least controversial and clearest coverage of certain aspects of contractual regulation with the current legislation of Ukraine: the order and scope of their application, the procedures for concluding and their subsequent dynamics, etc.

In our opinion, such division of contracts in the law of social security can be used in the process of the future reformation of the social-security legislation of Ukraine - Its codification.

Key words: contract, social security law, contractual regulation, individual contract, normative agreement.

Постановка проблеми та її актуальність. Для створення і подальшого вдосконалення законодавства, яке стосується будь-якої сфери життя в державі, необхідно враховувати всі об'єктивні умови його існування, що впливають на динаміку; організаційні, фінансові, інформаційні заходи, засобом яких здійснюється його реалізація. Не $є$ винятком у цьому сенсі сфера соціального захисту населення. Без дослідження договорів як одного з юридичних фактів, із яким законодавство пов'язує розвиток правовідносин у сфері соціального забезпечення населення, як регулятора суспільних відносин, як способу юридичного оформлення та вираження змісту правочину тощо це $\epsilon$ неможливим.

Аналіз останніх досліджень і публікацій. Як правило, питання договору та договірного регулювання становили науковий інтерес і продовжують його утримувати саме серед представників науки цивільного права. Окремі аспекти договірного регулювання сфери соціального забезпечення розглядалися лише у працях А.М. Лушнікова, М.В. Лушнікової та Н.Н. Тарусиної. Проте проаналізованими договори у сфері соціального забезпечення в сьогоднішніх українських реаліях досі не були, що слугувало поштовхом для обрання предмету дослідження - здійснення їх класифікації.

Метою статті $\epsilon$ класифікація договорів у праві соціального забезпечення.

Виклад основного матеріалу. Договорів у сфері соціального забезпечення - дуже багато. Крім того, різні підходи щодо розуміння даної правової категорії дають підстави ще більше примножити їх і так не малий об'єм, через, наприклад, можливість розширити перелік за рахунок двосторонніх міжнародно-правових домовленостей. Проте про це згодом.

Все розмаїття досліджуваного явища стає можливим усвідомити, систематизувавши існуючі договори. Впорядкувати будь-які об'єкти, явища, процеси, характеристики тощо можна, здійснивши їх класифікацію, найважливішим завданням якої $\epsilon$ з'єднання різних елементів, що часто можуть суперечити один одному, пошук таких суперечностей і їх усунення, а потім - формування уніфікованої, логічної, доступної для розуміння системи.

Для здійснення класифікації фундаментальне значення має обрання вдалих критеріїв для розмежуван-

Гудзь О. О., 2019 
ня елементів усієї сукупності договорів. Одночасно із теоретичним значенням, воно несе і вагоме практичне навантаження, адже впливає на правильне і чітке висвітлення їх у чинній нормативно-правовій базі, що суттєво спрощує та полегшує застосування норм права, а отже позитивно відзначається на досягненні найбільш глобальної цілі - ефективної реалізації права людини на соціальний захист.

Класифікації договорів свого часу присвячувало увагу багато українських і зарубіжних правників. Наприклад, Ю.А. Тихомиров диференціює усю багатоманітність договорів за суб'єктом і сферою застосування на: господарські, орендні, кредитні, у царині праці, міждержавні, управлінські, суспільні [1, с. 28, 30]. Із цього ряду логічно «виділяються» міжнародно-правові та управлінські договори. Крім того, поза увагою науковця залишився і ряд інших договорів (наприклад, сімейні та договори у сфері соціального забезпечення). Тобто, така класифікація як основа для досліджуваної нами сукупності договорів не $\epsilon$ вдалою.

Заслуговує на увагу класифікація договорів у праві соціального забезпечення, яку можна спостерігати у спільній монографії А.М. Лушнікова, М.В. Лушникової, Н.Н. Тарусиної «Договоры в сфере семьи, труда и социального обеспечения (цивилистическое исследование)»,проаналізувавши іï зміст. Учені поділяють ï на соціально-забезпечувальні міжнародні договори [2, с. 4]. Поділ їх лише на два види досить узагальнений, проте дає можливість у середині двох цих груп визначити низку інших видів, які можна виокремити, враховуючи їх власні особливості.

Наприклад, за суб'єктним складом договори у праві соціального забезпечення доцільно диференціювати на два види. Найбільш поширений, вочевидь, формат - це двосторонні договори. Сторони можуть бути різними: надавач та отримувач соціальної послуги (натуральної допомоги) у договорі про надання соціальної послуги; недержавний пенсійний фонд та його вкладник (у пенсійному контракті) тощо.

Для надання окремих видів соціального забезпечення характерним $\epsilon$ укладання тристоронніх договорів. Мова йде, у першу чергу, про договори медичного обслуговування населення за програмою медичних гарантій, відповідно до Закону України «Про державні фінансові гарантії медичного обслуговування населення»), де сторонами $\epsilon:$ надавач медичної послуги, який може залучати інших осіб для їі надання, замовник (який зобов'язується іï оплачувати), пацієнт. Чинне законодавство передбачає використання й інших тристоронніх договорів. Закон України «Про недержавне пенсійне забезпечення» закріплює можливих суб'єктів страхування: пенсійний фонд (або страхова організація, банк тощо), учасника недержавного пенсійного забезпечення та вкладника (це може бути і одна особа). Більше того, у разі запровадження загальнообов'язкового державного медичного страхування, такими сторонами буде: Фонд соціального страхування (або страхова організація), медичний заклад і застрахована особа (потенційний пацієнт).

Крім того, вказуючи серед видів договорів у праві соціального забезпечення міжнародні договори, слід вказати, що вони також можуть бути як дво-, так і багатосторонніми.

Наступним критерієм класифікації договорів у праві соціального забезпечення $\epsilon$ сфера їх застосування:
1) міждержавні (дво- або багатосторонні договори щодо соціального забезпечення, учасником яких $є$ Україна); 2) національні (Генеральна угода про регулювання основних принципів і норм реалізації соціально-економічної політики і трудових відносин в Україні від 23 серпня 2016 р., у якій закріплюються, наприклад, окремі питання соціального захисту працюючих тощо); 3) галузеві або міжгалузеві угоди (наприклад, Галузева угода на 2018-2020 роки між Міністерством інфраструктури України, Федерацією роботодавців транспорту України та профспілками працівників цивільної авіації містить окремий розділ (8), який починається із домовленості про сприяння створенню недержавного пенсійного фонду для працівників галузі); 4) регіональні (наприклад, Регіональна угода між Вінницькою обласною державною адміністрацією, Вінницькою обласною радою, організацією роботодавців та Федерацією профспілок Вінницької області на 2011-2015 роки); 5) локальні (наприклад, Колективний договір Національного університету «Одеська юридична академія» на 2015-2020 роки від 15 травня 2015 року містить Розділ 4. «Соціальна сфера НУ «ОЮА»); 6) індивідуальні. Проте така класифікація договорів цінна, на нашу думку, лише в якості напрацювань теорії права соціального забезпечення, адже у ній зібрані договори абсолютно різної правової природи, які скоріше складають сукупність, а не систему.

Договори у праві соціального забезпечення видається можливим розділити і на основі кількісного складу суб'єктів а також інтересу, який $є$ його об'єктом, на індивідуальні та колективні.

Право на соціальний захист, відповідно до тексту ст. 46 Конституції України мають громадяни України. У багатьох інших статтях законодавцем вживається слово «кожен», очевидно, що і згадане право не обмежується лише громадянами. Так, і договори у сфері соціального забезпечення можна диференціювати за колом осіб на ті, сторонами яких $\epsilon$ громадяни України, громадяни інших держав, особи без громадянства. Більше того, у випадку із міжнародними договорами - навіть держава.

За національною належністю досліджувані договори можна поділити на чинні міжнародні договори України в сфері соціального захисту населення; національні, прийняті на території України суб'єктами правотворчості. Окреме місце займають індивідуальні договори.

Абсолютно всі договори у праві соціального забезпечення можна поділити на групи, в залежності від рівня акту, у якому передбачається можливість його укладення та сфера застосування. Так це можуть бути ті, які передбачаються у законах i ті, укладання яких регулюється на рівні підзаконного нормативно-правового акту.

На нашу думку, найбільшу ясність і чіткість у розуміння системи договорів у праві соціального забезпечення внесе поділ їх на: нормативно-правові та індивідуальні із деталізацією видів в межах кожної із них.

Основна відмінність між даними групами договорів у тому, що одні із них визнаються в якості джерел права соціального забезпечення, інші - лише використовуються для упорядкування відносин між окремими суб'єктами.

Пилипенко П.Д. зазначає, що до актів договірного характеру, які дозволяється віднести до джерел права соціального забезпечення, належать універсальні та регіональні міжнародно-правові акти, двосторонні 
(локальні/партикулярні) договори України і внутрішньодержавні акти соціального діалогу [3, с. 93]. Таку думку поділяємо і ми.

Нормативно-правовий договір - акт договірної природи, у якому встановлюються обов'язкові для численного і формально не детермінованого кола осіб, розраховані на неодноразове використання правила поведінки (норми права), дія якого не припиняється залежно від того, виникли чи припинились відносини, на які він направлений [4, с. 335]. По суті, це такий договір, у якому закріплюються норми права.

Іншу велику групу договорів у праві соціального забезпечення складають індивідуально-правові договори. На відміну від нормативно-правових договорів, вони характеризуються визначеністю адресанта прав і обов'язків, закріплених у ньому; одноразовістю застосування його норм (або власне акту в цілому); припиненням дії договору після його реалізації [5]. Оригінальним $\epsilon$ твердження про те, що індивідуальні договори слугують своєрідною програмою майбутньої поведінки його учасників.

Цікавим $€$ те, що традиційне розуміння договору як виключно добровільного правовідношення із досліджуваними договорами не завжди спрацьовує. 3 огляду на даний факт, пропонуємо усі договори у праві соціального забезпечення на основі підстави їх укладання та подальшої динаміки диференціювати на: 1) ті, що укладаються в обов'язковому порядку - на основі вимог закону; 2) ті, укладання яких, зміна і припинення, відбуваються виключно на добровільній основі, на розсуд сторін. У першому випадку мова йде, наприклад, про договори у сфері медичної допомоги, загальнообов'язкового державного медичного страхування, з моменту, коли воно буде введено. Так договір $\epsilon$ обов'язковим елементом фактичного складу для виникнення соціально-забезпечувальних правовідносин даного виду. Інша група договорів складається із: 1) договорів у сфері соціального обслуговування, адже надання соціальних послуг носить виключно добровільний характер; 2) договорів у сфері недержавного пенсійного страхування; 3) договорів добровільного медичного страхування тощо.

Цивільно-правовий договір характеризується рівністю сторін. Як справедливо зазначають А.М. Лушніков, М.В. Лушникова, Н.Н. Тарусина, для договорів у праві соціального забезпечення така рівність не завжди властива. Аргументують тезу автори тим, що зміст правовідносин із надання певного виду соціального захисту населення встановлюється на рівні закону, а в добровільному соціальному забезпеченні - і договором, але, однаково, в законодавчих межах [1, с. 343]. На відміну від цього, для деяких договорів характерна рівність сторін, можливість самостійно визначати умови та порядок надання того чи іншого виду соціального захисту (наприклад, надання натуральної допомоги або соціальних послуг в порядку благодійності за рахунок такої організаційно-правової форми соціального захисту населення, як недержавне соціальне забезпечення). Отже, договори у досліджуваній сфері різняться за ступенем «втручання» держави в процес їх укладання та реалізації, і диференціюються на: ті, які носять виключно приватний характер, i ті, яким властива публічно-приватна правова природа.

Нормативно-правові договори у праві соціального забезпечення, перш за все необхідно поділити на між- народні договори і колективні договори і угоди. За змістом вони бувають: комплексні та спеціальні.

У свою чергу, міжнародно-правові договори у сфері соціального забезпечення, за критерієм безпосередності регулювання соціально-забезпечувальних відносин поділяються на прямі, тобто такі, у яких напряму встановлюються певні норми стосовно підтримки категорій населення, які цього потребують (майже всі міжнародні договори, що ратифіковані Україною), та непрямі, що регулюють соціально-забезпечувальні відносини абстрактно, у загальних рисах і не установлюють конкретних правил поведінки (договори, що містять принципи міжнародного права, акти застосування міжнародно-правих норм тощо).

Заслуговує на увагу поділ нормативно-правових договорів за дією в часі на: постійні і тимчасові. Прикладом перших $є$ міжнародні договори у сфері соціального захисту. Темпорально обмежений характер мають акти соціального діалогу (наприклад, Галузева угода між Міністерством освіти і науки України та Центральним комітетом Профспілки працівників освіти і науки України на 2016-2020 роки).

Особливе значення має класифікація саме індивідуальних договорів у праві соціального забезпечення, адже їх число і різноманітність дуже значні.

Розвиваючи думку, що договори у досліджуваній сфері відрізняються від цивільно-правових і тим, що мають публічно-правове наповнення, договори у праві соціального забезпечення за порядком встановлення умов доцільно поділити на: 1) ті, які укладаються із врахуванням побажань двох сторін (наприклад, пенсійні контракти у недержавному пенсійному страхуванні); 2) договори «приєднання» - тобто ті, умови яких встановлюються лише однією стороною-надавачем виду соціального захисту (приміром, договір про надання соціальних послуг, добровільна участь самозайнятих осіб, громадян, які проживають за кордоном, тощо у системі загальнообов'язкового державного соціального страхування).

За способом фінансування виконання зобов'язань за договорами щодо соціального забезпечення може здійснюватися а рахунок державного бюджету (наприклад, надання безоплатної соціальної послуги); інших джерел фінансування, зокрема коштів окремих фізичних осіб (наприклад, плані соціальні послуги, виплати за рахунок соціального страхування тощо).

Ще одним критерієм для виокремлення видів індивідуально-правових договорів у праві соціального забезпечення може слугувати така характеристика, як оплатність. На нашу думку, вона потребує додаткового пояснення. Так, у літературі зустрічаються різні терміни, які безпосередньо або опосередковано можуть стосуватись «ціни» договору: оплатний/безоплатний; безкоштовний/за плату тощо, але вони не $є$ тотожними.

У чинному законодавстві відсутнє визначення понять «оплатний договір» та «безоплатний договір». Напрацювання, висвітлені у спеціальній літературі, дають можливість розуміти, що оплатним вважається договір, за яким майнове надання однієї сторони зумовлює майнове (або нематеріальне) надання від іншої сторони або, іншими словами, - наявність зустрічного задоволення, яке має майнову цінність (найбільш яскравий приклад - договір із недержавного пенсійного страхування, де здійснення відповідних внесків спричинює виникнення у майбутньому права на отримання 
передбаченого виду пенсії). Безоплатний - не передбачає зустрічне майнове надання. У соціально-забезпечувальних правовідносинах, таким договором, наприклад, може регулюватись безкоштовна передача натуральної допомоги в порядку приватної ініціативи благодійника; договір гуманітарної допомоги.

Договір про надання соціальної послуги може одночасно бути і відплатним, і безоплатним - в залежності від того, на якій основі дані послуги надаються, адже перелік платних послуг чітко перебачений у Постанові Кабінету Міністрів України «Про порядок надання платних соціальних послуг та затвердження їх переліку» від 14.01.2004 р. № 12. Такий поділ договорів, на думку В.О. Гончаренко, має велике практичне значення, адже вирішує питання щодо обсягу прав і обов'язків сторін, про визначення відповідальності за обмеження або порушення прав [6, с. 240].

Із зазначеного вище випливає ще одна класифікація договорів у праві соціального забезпечення: ті, які передбачають надання видів соціального захисту безкоштовно та за окрему плату. У деякій мірі про це вже мова йшла.

Також договори у сфері соціального забезпечення доцільно розділяти залежно від виду соціального захисту, який становить предмет договору. Вважаємо не досить доцільним вдаватись у дискусію щодо питання виокремлення таких видів у теорії права соціального забезпечення через обмежений об'єм роботи, пропонуємо взяти за основу класифікацію, запропоновану свого часу Н.Б. Болотіною, яка на видається найбільш вдалою через максимальну розгорнутість та детальність. Так, вчена пропонує під видами соціального захисту населення розуміти: грошові виплати, пільги, натуральну допомогу, соціальне обслуговування, медичну допомогу, лікарські засоби, технічні засоби для реабілітації та пересування, інші вироби медичного призначення, житлово-комунальні субсидії [7, с. 107]. Проте, надання не всіх із перерахованих видів соціального захисту населення здійснюється на підставі договорів, це стосується лише соціальних послуг (у тому числі - натуральної допомоги); медичної допомоги і грошових виплат (мова йде про недержавне соціальне страхування).

Також, відштовхуючись від видів соціального захисту населення, які можуть становити предмет договору у досліджуваній сфері, та власне змісту і правової природи даного поняття, договори можна розділити на ті, які стосуються матеріальних благ (натуральної допомоги, грошових виплат) і нематеріальних - соціальних послуг.

Договори у сфері соціального забезпечення можна поділити за видами суспільних відносин, що регулюються за їх допомогою: 1) договори щодо соціального обслуговування; 2) договори у сфері пенсійного забезпечення; 3) договори у сфері охорони здоров'я.

Узагальнюючи класифікацію, запропоновану вище, договори слід диференціювати на страхові і нестрахові, відштовхуючись від того, які види соціального захисту населення передбачені системою соціального страхування (у першу чергу йдеться саме про недержавне пенсійне забезпечення, пізніше - i загальнообов'язкове державне медичне страхування), а які надаються за рахунок інших форм.

Висновки. Отже критеріїв для класифікації договорів у праві соціального забезпечення - дуже велика кількість. Це пояснюється, передусім, глибоко теоретичним характером даного питання, а отже - тісною залежністю між напрацьованими результатами дослідження та ступенем узагальнення або деталізації матеріалу авторами, впливом суб'єктивного уявлення про опрацьовану сукупність договорів в процесі виявлення їх спільних та відмінних рис з метою групування їх за видами. Більше того, така ситуація дозволяє виявляти все нові і нові відмінності між існуючими видами договорів, а отже пропонувати нові критерії для класифікації.

Проте, найбільш фундаментальним критерієм, на нашу думку, $\epsilon$ поділ усієї сукупності договорів у праві соціального забезпечення на нормативно-правові договори і індивідуальні. Така диференціація одночасно із теоретичним навантаженням відіграватиме важливу роль на практиці - впливатиме на найменш спірне і найбільш чітке висвітлення договірного регулювання діючому законодавстві України: порядку та сфери їх застосування, процедури укладання та їх подальшої динаміки тощо.

Ми переконані, що такий умовний поділ договорів у праві соціального забезпечення можна використати і в процесі майбутнього реформування соціально-забезпечувального законодавства України - його кодифікації.

\section{Література}

1. Тихомиров Ю.А. Договор как регулятор общественных отношений. Правоведение. 1990. № 5. С. 27-35.

2. Лушников А.М., Лушникова М.В., Тарусина Н.Н. Договоры в сфере семьи, труда и социального обеспечения (цивилистическое исследование): учебное пособие / А.М. Лушников, М.В. Лушникова, Н.Н. Тарусина; Яросл. гос. ун-т, 2008. Ярославль : ЯрГУ, 2008. 432 с.

3. Право соціального забезпечення : навч. посіб. для студ. юрид. спец. вищ. навч. закл. / П.Д. Пилипенко, В.Я. Бурак, С.М. Синчук та ін. / За ред. П.Д. Пилипенка. Київ : Видавничий дім «нЮре», 2006. 496 с.

4. Сташків Б.І. Право соціального забезпечення. Загальна частина : навч. посібник. Чернігів : ПАТ «ПВК «Десна», 2016. 692 с.

5. Індивідуальний договір в механізмі правового регулювання. URL: http://um.co.ua/2/2-16/2-163622.html.

6. Гончаренко В.О. Безоплатні договори за цивільним законодавством України. Актуальні проблеми держави $і$ права. 2010. № 56. С. 239-245.

7. Медвідь А.О. Соціальний захист бездомних осіб і безпритульних дітей : монографія. Одеса : Фенікс, 2016. 198 c.

Гудзь О. О., аспірантка кафедри трудового права та права соціального забезпечення Національного університету «Одеська юридична академія» 